\title{
Short Communication: \\ PCR detection of Avibacterium paragallinarum from layers with infectious coryza symptoms in poultry farms of Sleman District, Indonesia
}

\author{
IMA FAUZIAH ${ }^{1}$, WIDYA ASMARA ${ }^{2, v}$, AGNESIA ENDANG TRI HASTUTI WAHYUNI ${ }^{2}$, RINI WIDAYANTI ${ }^{3}$ \\ ${ }^{1}$ Doctoral Program of Veterinary Science, Faculty of Veterinary Medicine, Universitas Gadjah Mada. Jl. Fauna No. 2, Caturtunggal, Depok, Sleman \\ 55281, Yogyakarta, Indonesia \\ ${ }^{2}$ Department of Microbiology, Faculty of Veterinary Medicine, Universitas Gadjah Mada. Jl. Fauna No. 2, Caturtunggal, Depok, Sleman 55281, \\ Yogyakarta, Indonesia, Tel.: +62-274-6492088 Fax.: +62-274-560861, ’email: wied_as@ugm.ac.id \\ ${ }^{3}$ Department of Biochemistry, Faculty of Veterinary Medicine, Universitas Gadjah Mada. Jl. Fauna No. 2, Caturtunggal, Depok, Sleman 55281, \\ Yogyakarta, Indonesia
}

Manuscript received: 29 August 2021. Revision accepted: 19 October 2021.

\begin{abstract}
Fauziah I, Asmara W, Wahyuni AETH, Widayanti R. 2021. Short Communication: PCR detection of Avibacterium paragallinarum from layers with infectious coryza symptoms in poultry farms of Sleman District, Indonesia. Biodiversitas 22: 48904894. Infectious coryza (IC), caused by Avibacterium paragallinarum, is a contagious and infectious respiratory tract disease that affects the commercial poultry industry. Molecular techniques, such as species-specific PCR, HPG-2 PCR are mostly used for the detection of A. paragallinarum. The current research was carried out to isolate A. paragallinarum from the layers of infectious coryza signs in Sleman District, special region of Yogyakarta, followed by PCR confirmation of the identified bacteria. Nine field isolates were observed and determined based on their colony and cell morphology. All isolates were characterized biochemically and confirmed with species-specific HPG-2 PCR for A. paragallinarum. Out of 9 isolates, 6 (66.7\%) isolates were biochemically identified as A. paragallinarum and confirmed by HPG-2 PCR.
\end{abstract}

Keywords: Avibacterium paragallinarum, infectious coryza, layer, PCR

\section{INTRODUCTION}

Infectious coryza (IC) is an upper respiratory disease in chickens caused by Avibacterium paragallinarum (Biberstein \& White 1969) Blackall et al. (2005) (Akhtar et al. 2001; Blackall et al. 2005). IC is known as a disease with high morbidity but low mortality and may be acute to chronic (Bragg 2002; Akter et al. 2013). The economy impact of IC is associated with a significantly decreased egg production (10-40\%), increased number of culls chickens, weight loss, and increased medical costs (Tabbu 2000; Rajurkar et al. 2009; Ali et al. 2013). A. paragallinarum can infect all types of chickens in multiage farms (Akter et al. 2013).

The history of rapid disease spread, clinical signs, and lesions similar to IC symptoms can be confirmed through isolation and identification of $A$. paragallinarum for IC diagnosis (Tabbu 2008; Vegad and Katiyar 2008). Conventional diagnostic methods may be ineffective and may mislead infectious coryza and other poultry diseases. More sensitive and accurate methods are needed to diagnose and confirmation of A. paragallinarum. Two PCR tests have been developed for the identification of $A$. paragallinarum, one is conventional PCR (Chen et al. 1996) and the other is real-time PCR (both based on the same target) (Corney et al. 2008). Both PCRs are specific to A. paragallinarum, are fast and can detect all known variants. It has been verified that conventional PCR called HPG-2 PCR can be used for colonies on agar or mucus obtained by squeezing live chickens sinuses (Chen et al. 1996; Badouei et al. 2014). This PCR test is now routinely performed to identify the bacteria in nasal swabs and to confirm A. paragallinarum grown in the laboratory (Anjaneya et al. 2014). Poor sample quality, shipping delays, and poor quality (but expensive) media mean a higher rate of culture failure, making PCR an attractive diagnostic option (Blackall and Soriano-Vargas 2013). Compared with conventional PCR, real-time PCR has shown higher analytical sensitivity (10 to 100 times) (Corney et al. 2008). Currently, several alternative methods are used, such as ERIC-PCR (Soriano et al. 2004), ribotyping (Miflin et al. 1997), DNA restriction endonuclease analysis (Blackall et al. 1990), and 16S ribosomal RNA (rRNA) sequencing (Christensen et al. 2009) were found to be more accurate and sensitive tool for A. paragallinarum identification. A. paragallinarum serovar level recognition is tested extensively using HA-HI (Chukiatsiri et al. 2012). Recently, molecular serotyping based on multiplex PCR is also being used for molecular serotyping of pathogens (Sakamoto et al. 2012).

In 1970's A. paragallinarum was isolated and identified from sick layers of several farms in Bogor, West Java, Indonesia, but no isolates were maintained (Kusumaningsih and Poernomo 2000). IC was reported from various 
regions of Indonesia and can infect layers, broilers, local chickens, and quails (Poernomo et al. 2000; Wahyuni et al. 2018; Tangkonda et al. 2019), but there are few reports of A. paragallinarum in layers from Yogyakarta. According to previous studies, only Poernomo et al. (2000) used PCR for A. paragallinarum detection. Research on the molecular detection of $A$. paragallinarum in Indonesia is still limited. Since clinical signs and postmortem lesions are not pathognomonic, the diagnosis of IC should be confirmed.

The present research aimed to identify $A$. paragallinarum biochemically and PCR confirmation of the identified bacteria isolated from layers of infectious coryza signs in Sleman District, Yogyakarta, Indonesia.

\section{MATERIALS AND METHODS}

\section{Ethical approval}

Ethical approval does not require for this study because the samples were obtained from live animals without anesthetic treatment and in accordance with the standard sampling procedures without harm or necropting animals.

\section{Sample collection, isolation and biochemical characterization of $A$. paragallinarum}

The samples were obtained from 9 layers of IC signs such as malodorous nasal discharge and facial oedema from several farms in Sleman District, special region of Yogyakarta, Indonesia. The samples were collected from August-November 2019. The research was done in the Microbiology Department, Faculty of Veterinary Medicine, Universitas Gadjah Mada, Yogyakarta, Indonesia. The nasal exudate swabs were cultured on a chocolate agar plate (from blood agar medium (Oxoid), added 5\% sheep blood at $80^{\circ} \mathrm{C}$ ) and incubated in anaerobic jar for $24-48 \mathrm{~h}$ at $37^{\circ} \mathrm{C}$. Identification of bacteria was based on the colony morphology, cell morphology with Gram staining and biochemical tests (catalase test, oxidase test, urease test, motility test on semi-solid media, indole test, VP, and carbohydrates fermentation tests such as lactose, galactose, maltose, mannitol, and sorbitol) (Akter et al. 2016; Wahyuni et al. 2018).

\section{DNA extraction}

The identified isolates were cultured in brain heart infusion broth and incubated overnight at $37^{\circ} \mathrm{C}$. DNA was extracted from overnight grown cultures using Presto ${ }^{\mathrm{TM}}$ Mini gDNA Bacteria Kit (Geneaid Biotech Ltd., Taipei, Taiwan). The isolates were transferred to $1.5 \mathrm{~mL}$ microcentrifuge tube, then centrifuged for 1 minute at 14$16,000 \times \mathrm{g}$ then supernatant was discarded. $180 \mu \mathrm{L}$ of GT buffer was added into it and cell pellet was re-suspended by vortex or pipette. A $20 \mu \mathrm{L}$ of proteinase $\mathrm{K}$ was added and incubated at $60^{\circ} \mathrm{C}$ for at least 10 minutes. During incubation, the tubes were inverted for every $3 \mathrm{~min}$. A200 $\mu \mathrm{L}$ of GT buffer was added to the samples and mixed by vortex for 10 seconds then incubated at $70^{\circ} \mathrm{C}$ for at least 10 minutes to ensure the samples lysate was clear. At this time, elution buffer ( $200 \mu \mathrm{L}$ per sample) was pre-heated to $70^{\circ} \mathrm{C} .200 \mu \mathrm{L}$ of absolute ethanol was added to the samples lysate and mixed immediately by shaking vigorously. In a 2 $\mathrm{mL}$ collection tube, mixture was transferred to the GD (genomic DNA) column then centrifuged at 14-16,000 $\times \mathrm{g}$ for 2 minutes to bind DNA and to separate it from the supernatant. The flow-through $2 \mathrm{~mL}$ collection tube was discarded then GD column was placed in a new $2 \mathrm{~mL}$ collection tube. A $400 \mu \mathrm{L}$ of $\mathrm{W} 1$ buffer was added to GD column and centrifuged at $14-16,000 \times \mathrm{g}$ for 30 seconds then the flow-through was discarded. The GD column was reinserted in the $2 \mathrm{~mL}$ collection tube. $600 \mu \mathrm{L}$ of wash buffer was added to the GD column and centrifuged at 14$16,000 \times \mathrm{g}$ for 30 seconds then the flow-through was discarded. The GD column was placed back in the $2 \mathrm{~mL}$ collection tube and centrifuged for 3 minutes at 14-16,000 $\times \mathrm{g}$. The dried GD column was placed in a clean $1.5 \mathrm{~mL}$ microcentrifuge tube. To elute the pure DNA, $100 \mu \mathrm{L}$ of pre-heated elution buffer was added into the center of the column matrix then left for at least 3 minutes to allow the elution buffer to be thoroughly absorbed, then centrifuged at $14-16,000 \times \mathrm{g}$ for 30 seconds.

\section{HPG-2 PCR}

HPG-2 PCR protocol was performed as described previously by Chen et al. (1996) with some modifications in the temperature of PCR protocol. The species-specific $\sim 500$ bp fragment of $A$. paragallinarum was amplified using primers $\mathrm{F}$ (TGAGGGTAGTCTTGCACGCGAAT) and $\mathrm{R}$ (CAAGGTATCGATCGTCTCTCTACT). Each of $25 \mu \mathrm{L}$ reaction mixture was contained $12.5 \mu \mathrm{L}$ MyTaq HS Red Mix (Bioline), $1 \mu \mathrm{L}$ of each forward and reverse primer, $2 \mu \mathrm{L}$ of extracted template gene, and $8.5 \mu \mathrm{L}$ $\mathrm{ddH}_{2} \mathrm{O}$. The PCR protocol consisted of an initial denaturation at $94^{\circ} \mathrm{C}$ for $5 \mathrm{~min}$, followed by 35 cycles at $94^{\circ} \mathrm{C}$ for $30 \mathrm{sec}, 50{ }^{\circ} \mathrm{C}$ for $30 \mathrm{sec}, 72^{\circ} \mathrm{C}$ for $1 \mathrm{~min}$, and a final extension for $5 \mathrm{~min}$ in Infinigen Thermal Cycler (USA). The PCR products were checked using $1.5 \%$ agarose gel electrophoresis with FluoroSafe staining in 100 $\mathrm{mL}$ of $1 \times$ Tris/Borate/EDTA buffer solution.

\section{Data analysis}

The obtained data was analyzed descriptively based on the identification of $A$. paragallinarum by biochemical tests and HPG-2 PCR results.

\section{RESULTS AND DISCUSSION}

In the present study, nine layers that showed symptoms of IC, such as malodorous nasal discharge and swollen face were used as samples. After incubation period from nasal swabs of 9 layers with IC symptoms showed multiple colonies of different morphology. A. paragallinarum colonies mixed with other colonies were isolated by their typical transparent, tiny dew-drop colonies and identified as Gram negative and coccobacilli. From biochemical test results, 6 samples $(66.7 \%)$ had characteristics of $A$. paragallinarum, such as showing negative catalase test, oxidase test, indole test, urease test, VP, whereas results of motility test revealed that the bacterium was non-motile. Six isolates were able to ferment lactose, maltose, 
mannitol, and sorbitol and were unable to ferment galactose (Table 1). HPG-2 PCR was carried out to confirm six identified isolates and all isolates produced the expected size of $\sim 500$ bp amplicons (Figure 1). Based on the results, all six isolates were confirmed as $A$. paragallinarum. Whereas the results of the motility test on semi-solid media showed that this bacterium was immobile.

\section{Discussion}

In countries with tropical or subtropical climates, infectious coryza (IC) is considered an important disease to poultry farming (Feberwee et al. 2019). A. paragallinarum is a fastidious and slow-growing bacteria (Blackall 1999). The subsequent requirements for special media of $A$. paragallinarum make the identification of bacteria an expensive task (Morales-Erasto et al. 2014). In addition, $A$. paragallinarum is easily overgrown on bacteria that generally live in the upper respiratory tract and other contaminant bacteria, making it difficult to isolate (Morales-Erasto et al. 2014). Recently, the diagnostic options that can be used for IC have been expanded by identifying species-specific PCR, which can be used to identify A. paragallinarum (El-Sawah et al. 2012; Muhammad and Sreedevi 2015). During the present study, nine suspected layers of IC from several farms in Sleman District, special region of Yogyakarta showed signs of upper respiratory tract infections like sneezing, malodorous nasal discharge, swollen face, conjunctivitis, and lacrimation. The most prominent symptoms of IC are acute to chronic inflammation of the upper respiratory tract, including sinus with serous to mucoid nasal discharge, infraorbital sinus swelling, facial edema, conjunctivitis, and lacrimation (Bragg et al. 2002; Han et al. 2016).

Morphological colonies of 9 isolates showed round, small, and transparent colonies (such as dew-drops) similar to previous studies (Poernomo et al. 2000; Akter et al. 2016). Gram staining was carried out on the suspected colonies to confirm the morphology of the bacterial cells. Gram staining results showed that all nine isolates of suspected $A$. paragallinarum isolates were coccobacilli and Gramnegative. The results were in line with the previous research (Thenmozhi and Malmarugan 2013; Deshmukh et al. 2015).
Results of biochemical test (Table 1) showed that 6 isolates had negative results in catalase, oxidase, indole, VP, urease tests and were not motile. A similar finding was also reported by (Patil et al. 2016; Jeong et al. 2017; Wahyuni et al. 2018). All six isolates were able to ferment lactose, maltose, mannitol, and sorbitol, the similar results were obtained by other studies (Akter et al. 2014; Wahyuni et al. 2018; Tangkonda et al. 2019). All six isolates were unable to ferment galactose, this result was in accordance with other studies (Patil et al. 2016; Jeong et al. 2017; Feberwee et al. 2019). All the six isolates of $A$. paragallinarum were further confirmed with speciesspecific HPG-2 PCR test. All six field isolates of $A$. paragallinarum produced $\sim 500$ bp amplicon of the HPG-2 gene of the expected size (Figure 1). The PCR results of all six isolates of $A$. paragallinarum are consistent with the findings of previous study (Chen et al. 1996; Anjaneya et al. 2014; Patil et al. 2017). Chen et al. (1996) suggested that PCR is more sensitive than traditional methods of bacterial isolation and identification. Even after 60 days of storage at $20^{\circ} \mathrm{C}$, the HPG-2 PCR test diagnosed $A$. paragallinarum infection because conventional culture methods could not detect isolates even after 48 hours of storage (Anjaneya et al. 2014).

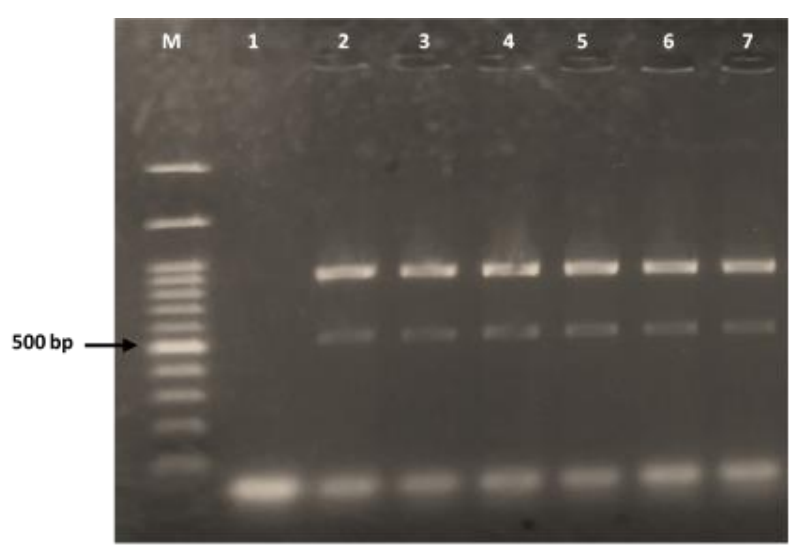

Figure 1. Molecular detection with HPG-2 PCR of Avibacterium paragallinarum isolates from layers. M: Marker: Marker/ladder DNA, $100 \mathrm{bp}$; 1: non-template control (NTC); 2-7: positive field layer isolates

Table 1. Biochemical test results of Avibacterium paragallinarum isolates

\begin{tabular}{|c|c|c|c|c|c|c|c|c|c|c|c|c|}
\hline Codes & Gram staining & $\mathbf{C}$ & $\mathbf{O}$ & $\mathbf{I}$ & $\mathbf{U}$ & $\mathbf{V P}$ & $\mathbf{M}$ & $\mathbf{L}$ & Sb & Mt & Mn & $\mathbf{G}$ \\
\hline L1 & Coccobacilli, Gram (-) & - & - & - & - & - & - & + & + & + & + & - \\
\hline L2 (-) & Coccobacilli, Gram (-) & + & - & + & - & - & + & + & + & + & + & - \\
\hline L3 & Coccobacilli, Gram (-) & - & - & - & - & - & - & + & + & + & + & - \\
\hline L4 & Coccobacilli, Gram (-) & - & - & - & - & - & - & + & + & + & + & - \\
\hline L5 & Coccobacilli, Gram (-) & - & - & - & - & - & - & + & + & + & + & - \\
\hline L6 & Coccobacilli, Gram (-) & - & - & - & - & - & - & + & + & + & + & - \\
\hline L7 & Coccobacilli, Gram (-) & - & - & - & - & - & - & + & + & + & + & - \\
\hline L8 (-) & Coccobacilli, Gram (-) & + & + & - & - & - & - & + & + & + & + & - \\
\hline L9 (-) & Coccobacilli, Gram (-) & + & - & + & - & - & + & + & + & + & + & - \\
\hline
\end{tabular}

Note: C: Catalase, O: Oxidase, I: Indole, U: Urease, VP: Voges-Proskauer, M: Motility, L: Lactose, Sb=Sorbitol, Mt: Maltose, Mn: Mannitol, G: Galactose. (+): Positive test and (-): Negative test 
PCR sensitivity is higher than traditional culture methods for the isolation and identification of $A$. paragallinarum (Durairajan et al. 2013). Using HPG-2 PCR tests instead of biochemical tests after the initial isolation can reduce the complexity and costs of diagnostic process. Another advantage of HPG-2 PCR method is its high rate as results are obtained after $24-48 \mathrm{~h}$ (Badouei et al. 2014).

The conclusion of this study is that six isolates $(66.7 \%)$ out of nine samples have been identified as $A$. paragallinarum from the biochemical test and confirmed by HPG-2 PCR test. The PCR method was found to be an efficient diagnostic tool for rapid and reliable diagnosis of IC and distinguishing A. paragallinarum from other nonpathogenic avian hemophilia bacteria and other respiratory tract bacteria. Further research on the pathogenicity test is needed to determine the virulence of the isolates. Sequencing of isolates is needed for the confirmation, and further molecular epidemiological studies about $A$. paragallinarum should be conducted, which could provide further information regarding the genomic variations of different field isolates in Indonesia, which will help in developing appropriate control strategies and prevention for IC.

\section{ACKNOWLEDGEMENTS}

This research was supported by Pendidikan Magister Menuju Doktor untuk Sarjana Unggul (PMDSU, contract number: 3176/UN1.DITLIT/DIT-LIT/PT/2020) Program from the Ministry of Research, Technology and Higher Education of the Republic of Indonesia.

\section{REFERENCES}

Akhtar S, Bhatti AR, Muhammad K. 2001. Clinico-therapeutic observations on an outbreak of infectious coryza. Intl J Agri Biol 3 (4): 531-532

Akter S, Ali M, Das PM, Hossain MM. 2013. Isolation and identification of Avibacterium paragallinarum, the causal agent of infectious coryza (IC) from layer chickens in Bangladesh. J Bangladesh Agril Univ 11(1): 87-96. DOI: 10.3329/jbau.v11i1.18218.

Akter S, Saha S, Khan KA, Amin MM, Haque ME. 2014. Isolation and identification of Avibacterium paragallinarum from layer chickens in Gazipur, Bangladesh. Microbes Health 3 (1): 9-11. DOI: 10.3329/mh.v3i1.19769.

Akter MR, Khan MSR, Rahman MM, Kabir SML, Khan MAS. 2016. Epidemic behavior of the etiological agent of infectious coryza in layer chicken of Bangladesh with isolation, identification, and pathogenicity study. Asian J Med Biol Res 2 (1): 82-94. DOI: 10.3329/ajmbr.v2i1.27573.

Ali M, Hossain S, Akter S, Khan MAHNA, Hossain MM. 2013. Pathogenesis of infectious coryza in chickens (Gallus gallus) by Avibacterium paragallinarum isolates of Bangladesh. Agriculturists 11 (1): 39-46. DOI: 10.3329/agric.v11i1.15240.

Anjaneya A, Singh SD, Dhama K, Wani MY, Gowthaman V. 2014 Isolation, antibiogram and PCR detection of Avibacterium paragallinarum from poultry flocks of India. J Pure Appl Microbiol 8 (5): 4181-4188.

Badouei MA, Saadrzadeh A, Azad N, Blackall P, Madadgar O, Charkhkar S. 2014. Isolation and molecular identification of Avibacterium paragallinarum in suspected cases of infectious coryza. Turk $\mathrm{J}$ Vet Anim Sci 38: 46-49. DOI: 10.3906/vet-1301-62.
Blackall PJ, Morrow CJ, Mcinnes A, Eaves LE, Rogers DG. 1990. Epidemiologic studies on infectious coryza outbreaks in Northern New South Wales, Australia, using serotyping, biotyping, and chromosomal DNA restriction endonuclease analysis. Avian Dis 34: 267-276. DOI: 10.2307/1591408.

Blackall PJ. 1999. Infectious coryza: overview of the disease and new diagnostic option. Clin Microbiol Rev 12 (4): 627-632. DOI: 10.1128/cmr.12.4.627.

Blackall PJ, Christensen H, Beckenham T, Blackall LL, Bisgaard M. 2005. Reclassification of Pasteurella gallinarum, [Haemophilus] paragallinarum, Pasteurella avium and Pasteurella volantium as Avibacterium gallinarum gen. nov., Avibacterium avium comb. nov and Avibacterium volantium comb. nov. Intl J Sys Evol Microbiol 55: 353-362. DOI: 10.1099/ijs.0.63357-0.

Blackall PJ, Soriano-Vargas E. 2013. Diseases of Poultry. 13th Edition. Blackwell Publishing, Iowa.

Bragg RR. 2002. Virulence of South African isolates of Haemophilus paragallinarum Part 1: NAD-dependent field isolates. Onderstepaart J Vet Res 69: 163-169.

Chen X, Miflin JK, Zhang P, Blackall PJ. 1996. Development and application of DNA probes and PCR tests for Haemophilus paragallinarum. Avian Dis 40 (2): 398-407. DOI: 10.2307/1592238.

Christensen H, Blackall PJ, Bisgaard M. 2009. Phylogenetic relationships of unclassified, satellitic Pasteurellaceae obtained from different species of birds as demonstrated by $16 \mathrm{~S}$ rRNA gene sequence comparison. Res Microbiol 160: 315-321. DOI: 10.1016/j.resmic.2009.05.006.

Chukiatsiri K, Sasipreeyajan J, Blackall PJ, Yuwatanichsampan S, Chansiripornchai N. 2012. Serovar identification, antimicrobial sensitivity and virulence of Avibacterium paragallinarum isolated from chickens in Thailand. Avian Dis 56 (2): 359-364. DOI: 10.1637/9881-080811-reg.1.

Corney BG, Diallo IS, Wright L, Hewitson G, de Jong A, Tolosa X, Burrell P, Duffy P, Rodwell B, Boyle DB, Blackall PJ. 2008. Rapid and sensitive detection Avibacterium paragallinarum in the presence of other bacteria using a 5' Taq nuclease assay: a new tool for diagnosing infectious coryza. Avian Pathol 37: 599-604. DOI: 10.1080/03079450802449139.

Deshmukh S, Banga HS, Sodhi S, Brar RS. 2015. An update on avian infectious coryza: it's re-emerging trends on epidemiology, etiologic characterization, diagnostics, therapeutic and prophylactic advancements. J Dairy Vet Anim Res 2 (3): 1-7. DOI: 10.15406/jdvar.2015.02.00037.

Durairajan R, Sharma M, Murugan MS. 2013. Detection of Avibacterium paragallinarum in commercial poultry and their antibiogram. Tamil Nadu J Vet Anim Sci 9 (4): 332-337.

El-Sawah A, Soliman YA, Shafey SM. 2012. Molecular characterization of Avibacterium paragallinarum strain used in evaluation of coryza vaccine in Egypt. J Am Sci 8 (3): 253-263.

Feberwee A, Dijkman R, Buter R, Soriano-Vargas E, Morales-Erasto V, Heuvelink A, Fabri T, Bouwstra R, de Wit S. 2019. Identification and characterization of Dutch Avibacterium paragallinarum isolates and the implications for diagnostics. Avian Pathol 48 (6): 549-556. DOI: 10.1080/03079457.2019.1641178

Han MS, Kim JN, Jeon EO, Lee HR, Koo BS, Min KC, Lee SB, Bae YJ, Mo JS, Cho SH, Jang HS, Mo IP. 2016. The current epidemiological status of infectious coryza and efficacy of PoulShot Coryza in specific pathogen-free chickens. J Vet Sci 17 (3): 323-330. DOI: 10.4142/jvs.2016.17.3.323.

Jeong OM, Kang MS, Jeon BW, Choi BK, Kwon YK, Yoon SY, Blackall PJ, Lee HS, Jung SC, Kim JH. 2017. Isolation and characterization of Avibacterium paragallinarum with different nicotinamide adenine dinucleotide requirements. Vet Microbiol 205: 62-65. DOI: 10.1016/j.vetmic.2017.05.005.

Kusumaningsih A, Poernomo S. 2000. Infeksius coryza (snot) pada ayam di Indonesia. Wartazoa 10 (2): 72-76. [Indonesian]

Miflin JK, Chen X, Blackall, PJ. 1997. Molecular characterisation of isolates of Haemophilus paragallinarum from China by ribotyping. Avian Pathol 27: 119-127. DOI: 10.1080/03079459708419199.

Morales-Erasto V, Posadas-Quintana JD, Fernández-Díaz M, Saravia LE, Martínez-Castañeda JS, Blackall PJ, Soriano-Vargas E. 2014. An evaluation of serotyping of Avibacterium paragallinarum by use of a multiplex polymerase chain reaction. Vet Diagn Invest 26: 272-276. DOI: $10.1177 / 1040638714523612$.

Muhammad TMN, Sreedevi B. 2015. Detection of Avibacterium paragallinarum by polymerase chain reaction from outbreaks of 
infectious coryza of poultry in Andhra Pradesh. Vet World 8 (1): 103108. DOI: $10.14202 /$ vetworld.2015.103-108.

Patil VV, Mishra DN, Mane DV. 2016. Isolation, characterization and serological study of Avibacterium paragallinarum field isolates from Indian poultry. $\mathrm{J}$ Anim Poult Sci 5 (1): 13-20. DOI: 10.5455/ijlr.20170209071608.

Poernomo S, Sutarma, Rafiee M, Blackall PJ. 2000. Characterisation of isolates of Haemophilus paragallinarum from Indonesia. Aust Vet $\mathbf{J}$ 78 (11): 759-762. DOI: 10.1111/j.1751-0813.2000.tb10447.x.

Rajurkar G, Roy A, Yadav MM. 2009. An overview on epidemiologic investigations of infectious coryza. Vet World 2: 401-403.

Sakamoto R, Kino Y, Sakaguchi M. 2012. Development of a multiplex PCR and PCR-RFLP method for serotyping of Avibacterium paragallinarum. J Vet Med Sci 74 (2): 271-273. DOI: $10.1292 / \mathrm{jvms} .11-0319$

Soriano VE, Tellez G, Hargis BM, Newberry L, Salgado-Miranda C, Vázquez JC. 2004. Typing of Haemophilus paragallinarum strains by using enterobacterial repetitive intergenic consensus-based polymerase chain reaction. Avian Pathol 48 (4): 890-895. DOI: $10.1637 / 7137$.

Tabbu CR. 2000. Penyakit Ayam dan Penanggulangannya: Volume 1. Penerbit Kanisius, Yogyakarta. [Indonesian]

Tangkonda E, Tabbu CR, Wahyuni AETH. 2019. Isolation, identification, and serotyping Avibacterium paragallinarum from commercial layer with snot symptoms. Jurnal Sain Veteriner 37 (1): 27-33. DOI: 10.22146/jsv.48489. [Indonesian]

Thenmozhi V, Malmarugan SJ. 2013. Isolation and identification and antibiogram pattern of Avibacterium paragallinarum from Japanese quails. Vet Anim Sci 9 (4): 253-258.

Vegad JL, Katiyar AK. 2008. A Textbook of Veterinary Special Pathology. International Book Distributing Co, Delhi.

Wahyuni AETH, Tabbu CR, Artanto S, Setiawan DCB, Rajaguguk SI. 2018. Isolation, identification, and serotyping of Avibacterium paragallinarum from quails in Indonesia with typical infectious coryza disease symptoms. Vet World 11 (4): 519-524. DOI: 10.14202/vetworld.2018.519-524 